\title{
Bio-inspired trypsin-chitosan cross-linked enzyme aggregates: a versatile approach for stabilization through carrier-free immobilization
}

\author{
Heidi AbDEl Mageed ${ }^{1,2 *}$, NeRmeEn Abuel EzZ ${ }^{3}$, RaSha RadWAN ${ }^{4}$ \\ ${ }^{1}$ Molecular Biology Department, Genetic Engineering and Biotechnology Division, National Research Centre, Cairo, Egypt \\ ${ }^{2}$ Faculty of Pharmaceutical Sciences and Pharmaceutical Industries, Future University in Egypt (FUE), Cairo, Egypt \\ ${ }^{3}$ Biochemistry Department, College of Pharmaceutical Sciences and Drug Manufacturing, \\ Misr University for Science and Technology, Cairo, Egypt \\ ${ }^{4}$ Biochemistry and Biotechnology Department, Faculty of Pharmacy and Drug Technology, Heliopolis University, Cairo, Egypt
}

\begin{abstract}
Enzymes are versatile catalysts for numerous industrial biocatalytic processes. Cross-linked enzyme aggregates (CLEAs) as a carrier free immobilization approach has drawn much attention being simple, cost efficient, capable of preserving high catalytic efficiency and improve enzyme reusability. The aim of this study was to develop a reusable, thermally and operationally stable trypsin CLEAs through co-aggregation with chitosan (CHS). Physicochemical characterization of the prepared CLEAs, including $\mathrm{pH}$ and temperature optimum, kinetic parameters, and operational and thermal stability in the absence (CLEA-T), and presence (CLEA-T-CHS) of CHS was carried out. CLEA-T-CHS and CLEA-T were prepared under mild conditions and cross linked using glutaraldehyde with $92 \%$ and $31 \%$ residual activity, respectively. Immobilized trypsin showed improved $\mathrm{pH}$ stability at alkaline $\mathrm{pH}$. At $70^{\circ} \mathrm{C}$ the immobilized enzyme had $62 \%$ residual activity while the free enzyme lost $91 \%$ of its initial activity. The kinetic parameters $\left(K_{m}\right.$ and $\left.V_{\max }\right)$ of the immobilized trypsin marginally increased, leading to a decreased catalytic efficiency. Operational and thermal stability were highly improved for CLEA-T-CHS; the half-life $\left(t_{1 / 2}\right)$ of free trypsin and CLEA-T-CHS were $15 \mathrm{~min}$ and $65 \mathrm{~min}$, respectively. Storage stability was highly improved; CLEAT-CHS and the free enzyme had $82 \%$ and $21 \%$ residual activity, respectively, after storage for 4 weeks. CLEA-TCHS retained $64 \%$ residual activity after five consecutive hydrolytic cycles, thus reinforcing its robust potentials. In this study, we successfully prepared a thermally stable and highly active immobilized trypsin through crosslinking in the presence of CHS. Results suggest that CLEA-T-CHS has great potential for industrial applications, including re-use in protein digestion.
\end{abstract}

Key words: cross-linked enzyme aggregates (CLEAs), trypsin enzyme, carrier-free immobilization, stability study, chitosan, reusability

\section{Introduction}

Biocatalysis is often perceived as the perfect response to the century's challenge of sustainable manufacturing processes. Enzymes are biocompatible and biodegradable catalysts originating from renewable resources. Enzymes catalyze reactions with high specificity and selectivity under mild conditions with high efficiency and often without requiring functional group activation, unlike other conventionally used methods (Sheldon, 2011a; Homoei, 2013). Unfortunately, enzymes such as trypsin have intrinsic limitations that hinder their potentials. They often suffer low operational and storage stability whereas; their activity is lost under industrial processing conditions such as temperature, $\mathrm{pH}$, and exposure to organic solvents. Immobilization techniques are usually applied to overcome these limitations (Mateo et al., 2007; Homoei, 2013). Immobilization using carrier support technique efficiently improves enzyme stability

\footnotetext{
* Corresponding author: Molecular Biology Department, Genetic Engineering and Biotechnology Division, National Research Centre, Cairo, Egypt; Faculty of Pharmaceutical Sciences and Pharmaceutical Industries, Future University in Egypt (FUE), Cairo, Egypt; e-mail: heidi.abdelmageed@gmail.com
} 
and resistance to harsh chemicals. Nonetheless, it causes enzyme dilution, leading to reduced activity and productivity and adds up to total cost, especially for expensive supports (Mateo et al., 2007; Li et al., 2018). Recently, researchers are developing special interest in immobilization by cross-linking of enzyme aggregates (CLEA) as a carrier-free immobilizing approach that offers high productivity and excludes extra costs of the support (Sheldon, 2011a; Li, 2018).

The CLEA methodology comprises two steps, precipitation and immobilization by cross-linking, that combine into a single process (Cao et al., 2000; Sheldon, 2011b; Velasco-Lozano, 2015). In brief, the first step involves precipitation of proteins from aqueous solutions as physical aggregates that are held together by noncovalent bonds (Burgess, 2009; Nader et al., 2016), followed by cross-linking of these physical aggregates into permanently insoluble ones through covalent coupling while preserving their conformational structure and, hence, their catalytic activity (Sheldon 2011b; Talekar et al., 2013). The CLEA approach allows permanent enzyme insolubility without disturbance to its conformational tertiary structure. It is a simple process that significantly enhances enzyme stability and performance over a broad range of temperatures and $\mathrm{pH}$. It has been shown that the activity and stabilization of the final CLEA product are dependent on the precipitating agent, cross-linker type and protective agents added during preparation (Li et al., 2018; Velasco-Lozano et al., 2015; Nader et al., 2016). Ammonium sulfate has been regularly used for selective precipitation and enzyme purification (Burgess, 2009). Glutaraldehyde has been used for decades as a traditional cross-linker for proteins owing to its availability, efficiency and low cost (Xu et al., 2018). However, the low content of lysine amino groups in the intended enzyme can drastically reduce the efficacy of glutaraldehyde as a cross-linker (Yamaguchi, 2011). Previous studies tried to address this setback by the addition of bovine serum albumin (BSA) (Shah et al., 2006) or polymers that are rich in primary amino groups as a protein feeder rich in amino groups to promote glutaraldehyde cross linking (Arsenault et al., 2011; Guimarães et al., 2018).

Chitosan (CHS) is a renewable, biocompatible and biodegradable polyaminosaccharide polymer that is characterized by its high affinity to proteins, mechanical strength and high resistance to chemical degradation (Krajewska, 2004; Wang et al., 2016). It is highly abundant, of low cost, and inert and its polyglucoseamine chains contain reactive amino and hydroxyl groups susceptible to chemical modifications. CHS is water insoluble; however, it is soluble in acidic solutions at $\mathrm{pH}$ less than 6.5. CHS has been commonly employed for enzyme immobilization (Wang et al., 2016). However, the objective of this study was to use the CHS polymer in the cross-linked complex with the trypsin enzyme rather than as binding support.

Trypsin (E.C.3.2.1.17) selectively hydrolyzes the arginine and lysine residues of proteins, is a substantial industrial biocatalyst used for protein digestion in the free soluble state or in gel form, and is also a common protein digestion reagent in the food industry. However, autolytic digestion and consequent loss of trypsin activity poses a major obstacle to its potential usage. Numerous immobilization approaches have often been employed to improve its industrial applications, including chemical and physical methods such as entrapment, covalent binding, and non-covalent adsorption (Sun et al., 2013; Jain et al., 2016; Sun et al., 2017). However, these immobilization methods often result in changes in specific catalytic activity, $\mathrm{pH}$ optimum, thermostability, and storage stability. Nonetheless, a common encountered problem was the poor reusability/recyclability of the immobilized trypsin. In order to improve reusability of trypsin, immobilized trypsin must possess significant activity, stability, and resistance to autolysis and proteolysis by other proteases. To overcome the drawbacks of conventional immobilization techniques, CLEA of trypsin were identified as potential candidates and investigated in this study. We expected that co-aggregation with $\mathrm{CHS}$ would maintain trypsin's conformational structure during the cross-linking process consequently, enhancing its catalytic efficiency and stability. To our knowledge, using CHS a protective agent during the preparation of CLEA of trypsin (CLEA-S) has not been fully exploited. To investigate our proposition, we prepared CLEA-T, and CLEA-T-CHS, and carried out physicochemical characterization for optimum $\mathrm{pH}$ and temperature, kinetic parameters, recycling, storage, operational, and thermal stability and compared them to those of the free enzyme.

\section{Materials and methods}

\section{Chemicals}

Trypsin bovine pancreas $(3.4 .21 .4 ; 3.5 \mathrm{U} / \mathrm{mg})$, ammonium sulphate, glutaraldehyde $(25 \% \mathrm{w} / \mathrm{v}$ solution), 
N- $\alpha$-benzoyl-DL-arginine-p-nitroanilide (BAPNA), Bovine serum albumin (BSA) were purchased from Sigma-Aldrich (St. Louis, MO, USA). Chitosan was purchased from Fluka, Germany. All other reagents were of analytical grade. All experiments were performed in triplicate.

\section{Enzyme activity and protein concentration assays}

Trypsin activity was determined using a hydrolytic assay where the product of enzymatic catalysis of the L-BAPNA substrate prepared in dimethylsulfoxide was measured by using a spectrophotometer (UV-2600 spectrophotometer, Schimadzu). The reaction mixture was incubated at room temperature for 10 minutes. The release of yellow p-nitroaniline (p-NA) was determined spectrophotometrically at a wavelength of $405 \mathrm{~nm}$ (405A) (Daglioglu and Zihnioglu, 2012; Menfaatli and Zihnioglu, 2015). One activity unit (U) of trypsin is defined as the amount of enzyme hydrolyzing $1 \mu \mathrm{mol}$ of $\mathrm{N}$ - $\alpha$-benzoylDL-arginine-p-nitroanilide per minute under standard assay conditions. Protein concentration was determined by the Bradford method (Bradford, 1979), using BSA as standard.

\section{Preparation of trypsin CLEA}

CLEA were prepared in two steps: first enzyme precipitation and second cross linking (Suleka et al., 2011; Jian and Shi, 2015). The precipitant (60\% ammonium sulfate) was slowly added under stirring to trypsin solution $(10 \mathrm{mg} / \mathrm{ml})$ prepared in $100 \mathrm{mM}$ sodium phosphate buffer, $\mathrm{pH}$ 7.5. Precipitation was optimized by the absence of enzymatic residual activity in the supernatant. The resulting mixture was retained for $24 \mathrm{~h}$ at $4^{\circ} \mathrm{C}$. The aggregates formed were separated by centrifugation (15000 rpm, $20 \mathrm{~min}$ ) and were re-suspended in $100 \mathrm{mM}$ sodium phosphate buffer, $\mathrm{pH}$ 7.5. The cross linking step was carried out subsequently with glutaraldehyde ( $25 \% \mathrm{w} / \mathrm{w}$, Sigma Aldrich) as the cross linker. Glutaraldehyde was gradually added (at the final concentration of $1 \% \mathrm{v} / \mathrm{v}$ ) to $5 \mathrm{ml}$ of trypsin aggregate suspension allowing for cross linking time of 3 hours. The CLEA-T formed was recovered by centrifugation at $15000 \mathrm{rpm}$ for $15 \mathrm{~min}$ at $4^{\circ} \mathrm{C}$ and were finely dispersed in $100 \mathrm{mM}$ sodium phosphate buffer ( $\mathrm{pH} 7.5$ ) and stored at $4{ }^{\circ} \mathrm{C}$ for subsequent activity analysis. The ease of separation and complete recovery of the prepared CLEAs from aqueous medium by centrifugation is one of the major advantages of this procedure.

\section{Preparation of CLEA-T-CHS}

CHS (mean molecular weight of $750 \mathrm{kDa}$ and $64 \%$ deacetylated) was solubilized using $0.1 \mathrm{M} \mathrm{HCl}$. To ensure complete dissolution, the solution was sonicated in a sonification bath for $1 \mathrm{~h}$. CHS solution $(100 \mathrm{mg} / \mathrm{ml})$ was added drop wise with a flat-tip needle $(0.5 \mathrm{ml} / \mathrm{min})$ to trypsin aggregate suspension ( $\mathrm{pH}$ 8.0) (CHS concentration was chosen based on preliminary study, data not shown). CHS is not soluble at high $\mathrm{pH}$ (above 6.5); hence, the added drops solidify and co-aggregate and co-precipitate with trypsin. In order to form an activated covalent crosslinked network between trypsin and CHS, glutaraldehyde was added drop-wise. Hence, a second step followed with gradual addition of glutaraldehyde (at the final concentration of $1 \% \mathrm{v} / \mathrm{v}$ ), allowing for cross linking time of 3 hours. Glutaraldehyde reacts with the primary amine groups of trypsin and CHS forming Schiff bases.

The residual activities of the prepared CLEAs are expressed as percentages of the initial activity of the enzyme (taken as 100\%) according to the Equation 1:

$$
\text { Residual activity }[\%]=\frac{\text { Total activity of CLEA }[\mathrm{U}]}{\begin{array}{c}
\text { Total free enzyme activity used } \\
\text { for CLEA preparation }[\mathrm{U}]
\end{array}} \times 100
$$

All experiments were carried out in triplicate and enzyme assay measurements were carried out under standard assay conditions at $25^{\circ} \mathrm{C}$.

\section{pH and temperature optimum determination}

The effect of $\mathrm{pH}$ on the enzymatic activity of the free enzyme and CLEA was determined at various $\mathrm{pH}$ values ranging from $\mathrm{pH} 4.0$ to $\mathrm{pH} 10.0$ using the following buffers: $0.05 \mathrm{M}$ Glycine- $\mathrm{HCl}(3.0-4.0)$, acetate (4.0-5.0), succinate $(6.0-6.5)$, potassium phosphate $(6.5-8.0)$, Tris- $\mathrm{HCl}(8.0-9.0)$. Optimum temperatures of the free enzyme and CLEAs were estimated by measuring the enzyme activity over a temperature range of $20-70^{\circ} \mathrm{C}$. The residual enzyme activity was determined under standard assay conditions.

\section{Kinetic parameters of CLEAs}

The kinetic parameters $V_{\max }, K_{m}$, and catalytic efficiency $\left(V_{\max } / K_{m}\right)$ values of prepared CLEAs prepared were determined using the Lineweaver-Burk plot of the Graph Pad Prism program (version 5.0) by measuring the enzyme activity at different concentrations of the 
enzyme substrate. The turnover number $\left(K_{c a t}\right)$ was calculated using the following equation: $K_{c a t}=V_{\max } /[\mathrm{E}]$, where [E] is the enzyme concentration and $V_{\max }$ is the maximum velocity (Liu et al., 2017).

\section{Stability studies}

For all stability experiments carried out, enzyme activity was measured under standard assay conditions. The initial activity at zero time was considered as $100 \%$ and the residual activity (\%) was calculated at different time intervals.

\section{Thermal stability}

Thermal stability was determined by incubating the prepared CLEAs and the free trypsin enzyme at different temperatures $\left(40^{\circ} \mathrm{C}, 50^{\circ} \mathrm{C}\right.$ and $\left.60^{\circ} \mathrm{C}\right)$ for 120 min with continuous shaking at $200 \mathrm{rpm}$ in an aqueous buffer (100 mM sodium phosphate, $\mathrm{pH}$ 7.5).

\section{Operational stability}

Operational stability of the trypsin CLEAs was examined according to the method described by Menfaatli and Zihnioglu (2015) in a reaction solution composed of $0.5 \mathrm{ml}$ trypsin CLEA, $4 \mathrm{ml} 100 \mathrm{mM}$ sodium phosphate buffer (pH 7.5), $0.5 \mathrm{ml} 0.9 \% \mathrm{NaCl}$ and $2.5 \mathrm{ml} 0.1 \%$ BAPNA (enzyme substrate). The reaction was kept at $37^{\circ} \mathrm{C}$ with continuous shaking for $6 \mathrm{~h}$. Samples were collected at designated time intervals. The residual enzyme activity was determined under standard assay conditions and the half-lifes $\left(t_{1 / 2}\right)$ of the immobilized and the free trypsin were calculated.

\section{Storage stability}

The storage stability of both, the free enzyme and CLEAs, were determined at different time intervals after storage for 4 weeks in sodium phosphate buffer (100 mM, pH 7.5) at $4{ }^{\circ} \mathrm{C}$.

\section{Reusability}

The reusability of the prepared CLEAs was determined by subjecting them to six successive hydrolytic cycles. After each hydrolytic cycle, the immobilized enzyme (CLEA-T-CHS) was collected using centrifugation (10000 rpm, $20 \mathrm{~min}, 4^{\circ} \mathrm{C}$ ), washed three times using sodium phosphate buffer (100 mM, pH 8) and re-suspended in a fresh reaction mixture. Residual trypsin activity was calculated after every cycle under standard assay conditions at $25^{\circ} \mathrm{C}$. The initial activity of the immobilized trypsin was assigned as 100\% (relative activity).

\section{Statistical analysis}

All experimental measurements were performed in triplicate. The statistical significance of the differences in each trial was evaluated using one-way analysis of variance and the results were presented as mean \pm standard deviation (SD). The limit for statistical significance was $P<0.05$.

\section{Results and discussion}

\section{Preparation of trypsin CLEAs}

Trypsin is one of the most versatile enzymes used for protein digestion. However, it exhibits low stability in the free form. Therefore, in this study the trypsin enzyme was irreversibly, covalently immobilized by crosslinking, forming CLEAs. CLEAs are usually prepared by following a two-step protocol. Step one involves enzyme precipitation and the cross linking takes place in step two. In this study, ammonium sulfate was chosen for precipitation of trypsin as a mild precipitant and preferred over other organic solvents due to its minimal effect on enzyme activity (Velasco-Lozano et al., 2015). Precipitation using ammonium sulfate was previously reported by several authors (López-Serrano et al., 2002; Yu et al., 2006; Menfaatli and Zihnioglu, 2015). The second stage of CLEA preparation is the cross-linking step of the precipitated enzyme aggregates. At this point they are physically held together by non-covalent bonds and a crosslinking step is required to form the insoluble state. Glutaraldehyde is a widely used, versatile cross-linking agent of low cost and high availability. In order to obtain the highest residual activity recovery, the cross-linking step was carried out using $5 \mathrm{ml}$ of trypsin aggregate cross-linked using glutaraldehyde at $1 \%(\mathrm{v} / \mathrm{v})$ final concentration.

CLEAs which were prepared in the presence of CHS showed a significant increase in residual activity. The residual activity percentage determined in the presence of CHS was $92 \%$, with $99 \%$ immobilization yield. On the other hand, $31 \%$ residual activity and $80 \%$ immobilization yield was recorded without CHS. Therefore, CLEA-TCHS was chosen for further physicochemical characterization in this study. The presence of reactive amino groups CHS makes it a potential candidate for enzyme binding. CHS increases the free amino group concentration available for cross-linking, thus preventing the denaturation of the targeted trypsin enzyme and mediating 
a substantial cross-linking with retention of high enzymatic activity (Kamburov and Lalov, 2012; Li et al., 2018). For CHS, the cross-linking reaction occurs at a higher rate at $\mathrm{pH}>6.5$ when the $\mathrm{CHS} \mathrm{NH}_{2}$ groups are deprotonated. Glutaraldehyde acts as an amino-fixing arm, forming covalent imine bonds with the amino groups, both in CHS and trypsin (Kamburov and Lalov, 2012; Sun et al., 2017).

\section{Physico-chemical characterization of trypsin CLEAs}

\section{Effect of temperature on trypsin activity}

The influence of temperature on the catalytic activity of free and the immobilized trypsin was studied at different temperatures (from $20-70^{\circ} \mathrm{C}$ ). The results are shown in Figure 1. The free enzyme showed maximum activity at $37^{\circ} \mathrm{C}$, and above this temperature a steep decrease in enzyme activity was observed. On the other hand, CLEAs showed improved stability at all tested temperatures and exhibited maximum activity between $40-50{ }^{\circ} \mathrm{C}$, and hence, exhibited higher thermostability than the free enzyme. The free enzyme suffered from denaturation above the optimum temperature $\left(37^{\circ} \mathrm{C}\right)$ while the immobilized trypsin was more resistant to denaturation. This can be explained by the stable, rigid structure of the enzyme due to cross-linking of its amino groups by covalent bonding, causing a reduction in its conformational flexibility, and hence protecting the enzyme against thermal denaturation (Homaei et al., 2013; Singh et al., 2013).

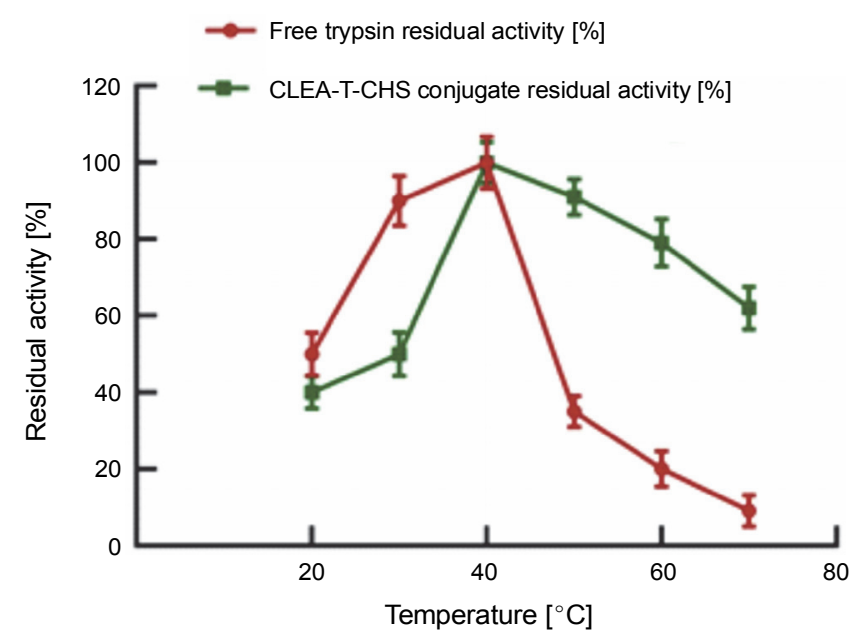

Fig. 1. Effect of temperature on catalytic activity of free and immobilized trypsin (Cross-linked enzyme aggregates-T-chitosan CLEA-T-CHS)) at various temperatures from $20-70^{\circ} \mathrm{C}$

\section{Effect of $\mathrm{pH}$ on trypsin activity}

The effect of $\mathrm{pH}$ value on the activity of the free and immobilized trypsin was examined by varying the $\mathrm{pH}$ value. The results are presented in Figure 2. The optimum $\mathrm{pH}$ value for both free and immobilized enzyme was determined at $\mathrm{pH}$ 8.0. In addition, immobilized trypsin showed higher activity compared to the free trypsin enzyme, both at $\mathrm{pH} 6.0$ and at alkaline $\mathrm{pH}(\mathrm{pH}$ 9.0 ). These results are in accordance with previous results described in literature, where improved $\mathrm{pH}$ stability of enzymes upon immobilization was reported for trypsin (Menfaatli and Zihnioglu, 2015; Sun et al., 2017), lipase (Mohamed et al., 2011) and catalase (Abdel-Mageed et al., 2012) were reported.

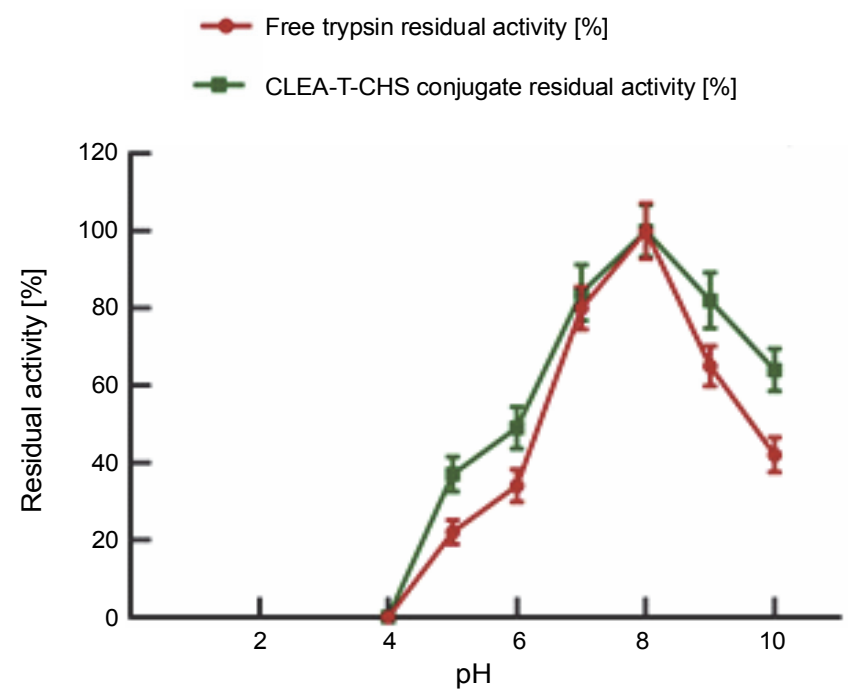

Fig. 2. Effect of pH on catalytic activity of free and immobilized trypsin (CLEA-T-CHS) at various $\mathrm{pH}$ values (4.0-9.0)

\section{Determination of kinetic parameters}

For a comprehensive evaluation of the effect of immobilization on trypsin activity, an assessment of the change in hydrolytic activity was carried out by determining the Michaelis constant $\left(K_{m}\right)$ and the maximum hydrolysis reaction rate $\left(V_{\max }\right)$ for free and immobilized trypsin (Table 1). The $K_{m}$ for free trypsin was $1.49 \mathrm{mM} / 1$, whereas for immobilized trypsin it was slightly higher $\left(K_{m}=\right.$ $1.89 \mathrm{mM} / \mathrm{l})$. As the $K_{m}$ values were of the same magnitude, we concluded that the immobilization process employed did not impair the catalytic function of the enzyme. The results obtained for the kinetic study indicated lower affinity of the enzyme towards the substrate 
Table 1. Kinetic parameters $\left(\mathrm{K}_{\mathrm{m}}, \mathrm{V}_{\mathrm{max}}, \mathrm{K}_{\mathrm{cat}}\right)$ and enzymatic efficiency of free and immobilized trypsin enzyme (Cross-linked enzyme aggregates-T-chitosan (CLEA-T-CHS))

\begin{tabular}{c|c|c|c|c}
\hline Enzyme sample & $\begin{array}{c}K_{m} \\
{[\mathrm{mM} / \mathrm{l}]}\end{array}$ & $\begin{array}{c}V_{\max } \\
{\left[\mu \mathrm{mol} \cdot 1^{-1} \cdot \mathrm{min}^{-1}\right]}\end{array}$ & $\begin{array}{c}\text { Enzymatic } \\
\text { efficiency } \\
\left(V_{\max /} K_{m}\right)\end{array}$ & $\begin{array}{c}K_{c \text { cat }} \\
{\left[\mathrm{S}^{\text {- }}\right]}\end{array}$ \\
\hline Free Trypsin & 1.49 & 1.73 & 1.048 & 0.199 \\
\hline CLEA-T-CHS & 1.89 & 2.13 & 1.23 & 0.236 \\
\hline
\end{tabular}

which might be a consequence of the lower accessibility of the immobilized enzyme's active site, which could be attributed to different factors such as conformation changes due to covalent coupling or steric effect of the polymer. Other authors have reported similar findings where enzyme substrate affinities have decreased upon immobilization (Mahmod et al., 2016; Abdel-Mageed et al., 2019).

$V_{\max }$ and the turnover number $\left(K_{c a t}\right)$ of immobilized trypsin were higher than that of free trypsin which could indicate a higher diffusion rate, resulting in the increase of the reaction rate of trypsin upon immobilization. $V_{\max }$ of the free and immobilized enzyme were 1.73 and $2.13 \mu \mathrm{mol} \cdot 1^{-1} \cdot \min ^{-1}$, respectively. $V_{\max }$ value is an indication of how fast the enzyme can hydrolyze a completely saturated substrate; hence higher $V_{\max }$ value on immobilization indicates that less substrate is needed to be converted to a product per unit time. It is notable that the CLEA structure has less interfacial interaction with the substrate as a result of cross-linking as compared to the free enzyme. Also, the catalytic efficiency $\left(V_{\max } / K_{m}\right)$ of immobilized trypsin was higher than that of the free enzyme (Table 1). Comparable results have been reported by other authors (Yu et al., 2013; Abdel-Mageed et al., 2019).

\section{Operational and thermal stability of free and immobilized trypsin}

Immobilization techniques are commonly used to overcome the intrinsic liability of enzymes, especially toward industrial processing conditions. Thermal stability study for both free and immobilized trypsin was investigated at various temperatures. Results showed that immobilized trypsin (CLEA-T-CHS) exhibited better thermal stability at all examined temperatures (Fig. 3). As presented in Figure 3, CLEA-T-CHS retained 64\% residual stability at $60^{\circ} \mathrm{C}$ while, the free enzyme lost $90 \%$ of its activity at the same temperature. The improvement in thermal stability upon immobilization can be

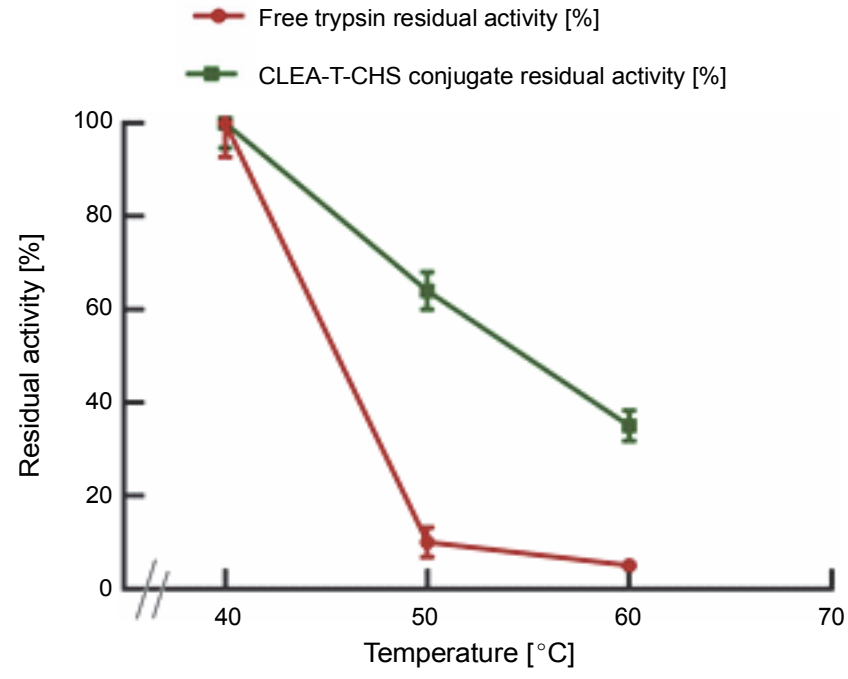

Fig. 3. Thermal stability of free and immobilized trypsin (CLEAT-CHS) measured at different temperatures; residual catalytic activity was determined under standard assay conditions

attributed to the covalent cross-linking of the enzyme that increases the rigidity of the enzyme structure, and hence, avoids conformational modifications and loss of enzyme activity.

Operational stability measured the change in the enzyme activity during reaction time. Half-life $\left(t_{1 / 2}\right)$ of the enzyme is the time required for the enzyme to lose $50 \%$ of its initial activity. Half-life can be calculated by the following equation Equation 2:

$$
t_{1 / 2}=\ln 2 / k_{D}=2.303 / t \times \log \left(A_{0} / A\right)
$$

where $t_{1 / 2}$ - half-time, $k_{D}$ - decay coefficient, $A$ - activity, $A_{0}$ - initial activity.

A batch-stirred approach was used to evaluate the operational stability of the immobilized trypsin enzyme at $37^{\circ} \mathrm{C}$. Samples were withdrawn from the reaction medium at different time intervals and enzyme activity was measured under standard assay conditions. The half-life $\left(t_{1 / 2}\right)$ of free trypsin and CLEA-T-CHS were $15 \mathrm{~min}$ and 


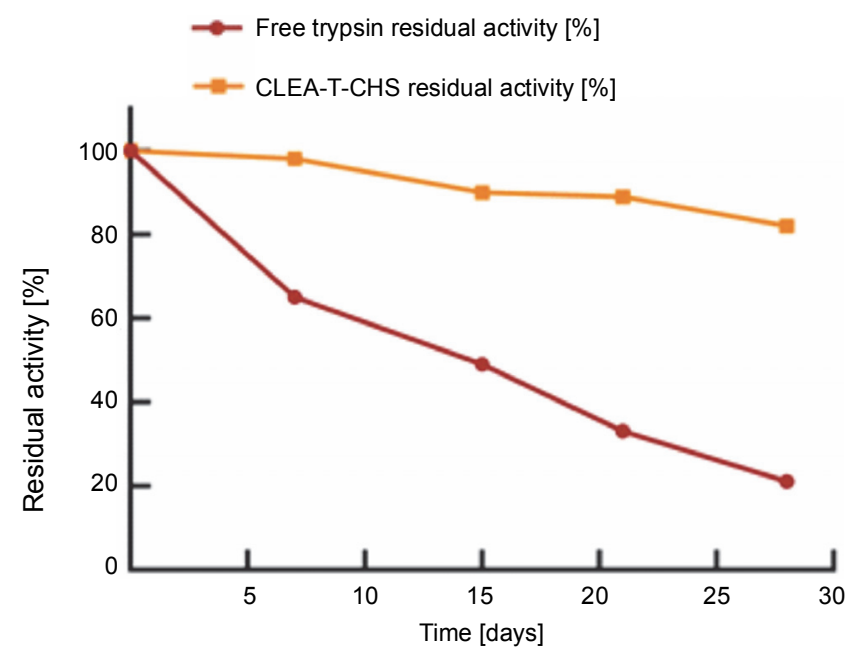

Fig. 4. Storage stability of immobilized trypsin (CLEA-T-CHS); residual catalytic activity was determined at different time intervals under standard assay conditions upon storage at $5{ }^{\circ} \mathrm{C}$

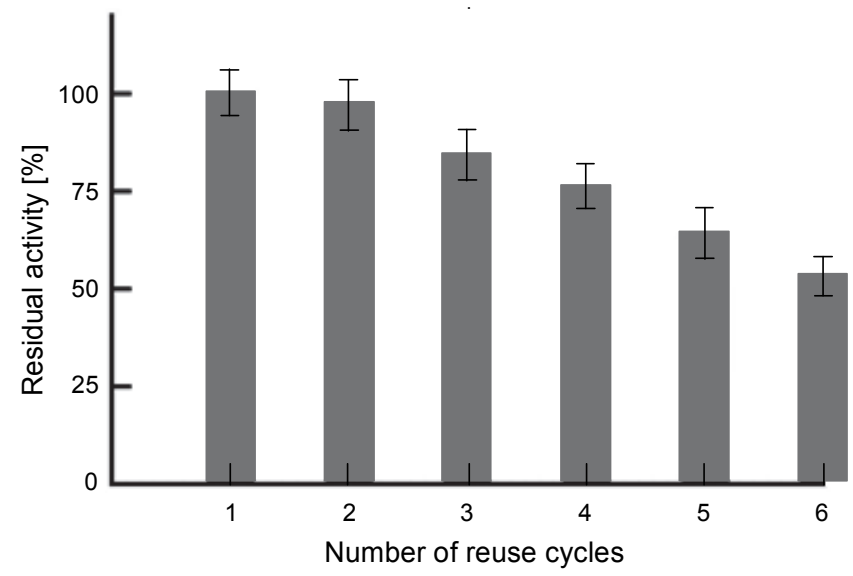

Fig. 5. Reusability of CLEA-T-CHS in repeated hydrolytic cycles; residual activity of the immobilized trypsin (in \%) after six cycles of repeated use (initial activity was taken as 100\%)

$65 \mathrm{~min}$, respectively. Xu et al. (2013) reported improved thermal stability of CLEAs as compared to the free enzyme, because of the rigid structure resulting from cross-linking. In addition, Kim et al. (2013) stated that prepared CLEAs showed four times higher thermal stability as compared to the free enzyme.

\section{Reusability and storage stability of free and immobilized trypsin}

Industrial applications of enzymes are usually constrained by their limited shelf life and reusability. Resistance of CLEA-T-CHS towards operational stress is substantial and fundamental for the enzyme's prospective applications. Figure 4 shows storage stability of free and immobilized trypsin (CLEA-T-CHS). Immobilized trypsin and free trypsin retained $82 \%$ and $21 \%$ of their initial activity, respectively, after storage for 4 weeks. Shelf-life results show that immobilization highly stabilized the trypsin enzyme in comparison to the free one. Reusability allows multiple re-cycling of the same enzyme. CLEAs being insoluble can be easily separated from the reaction medium, washed and reused; hence the downstream process can be implemented easily. Reusability of the prepared trypsin CLEA-T-CHS was examined for 6 consecutive enzymatic cycles (Fig. 5). The immobilized enzyme retained $64 \%$ of its initial activity after 5 cycles. The reason for observed loss in enzymatic activity could be due to subjecting the trypsin enzyme to mechanical stress during consecutive centrifugation cycles which might have caused conformational and morphological changes (Dalal et al., 2007; Mahmod et al., 2016). An observed enhancement of enzyme re-usability was reported earlier for different enzymes using various immobilization techniques such as catalase (Abdel-Mageed et al., 2018), $\alpha$-amylase (Talekar et al., 2012; Abdel-Mageed et al., 2019), and trypsin (Sun et al., 2013; Mahmod et al., 2016).

\section{Conclusions}

CLEA proved to be an attractive immobilization approach as evidenced by the ease of preparation and separation, lower cost, applicability to practically every enzyme and simple adaptation and optimization. The CLEA approach produces stable, recyclable biocatalysts with high residual activity (92\%) making it a versatile tool for biocatalysis processes. The results of our study showed that the methodology used for immobilization of the trypsin enzyme, co-aggregated with CHS polysaccharide via glutaraldehyde cross-linking, was effective in enhancing trypsin thermal, operational, and storage stabilities and reusability. In addition, it is a simple and reproducible method with minimal requirements for advanced instruments. In conclusion, the results shown in this study suggest that CLEA-trypsin can be a promising approach for improving the stability and reusability of trypsin in biotechnological applications.

\section{References}

Abdel-Mageed H., El-Laithy H., Mahran L., Fahmy A., Mäder K., Mohamed S. (2012) Development of novel flexible sugar ester vesicles as carrier systems for the antioxidant en- 
zyme catalase for wound healing applications. Process Biochem. 47: 1155-1162.

Abdel-Mageed H., Fahmy A., Dalia S., Mohamed S. (2018) Development of novel delivery system for nanoencapsulation of catalase: formulation, characterization, and in vivo evaluation using oxidative skin injury model. Artif Cells. Nanomed. Biotechnol. 24: 362-371. DOI: 10.1080/21691401. 2018.1425213.

Abdel-Mageed H., Radwan R., AbuelEzz N., Nasser H., El Shamy A., Abdelnaby R. El Gohary N. (2019) Bioconjugation as a smart immobilization approach for $\alpha$-amylase enzyme using stimuli responsive Eudragit-L100 polymer: a robust biocatalyst for applications in pharmaceutical industry. Artif. Cells Nanomed. Biotechnol. 47(1): 2361-2368.

Arsenault A., Cabana H., Jones J. (2011) Laccase-based CLEAs. chitosan as a novel cross-linking agent. Enzyme Res. DOI: 10.4061/2011/376015.

Bradford M. (1976) A rapid and sensitive method for the quantitation of microgram quantities of protein utilizing the principle of protein-dye binding. Anal. Biochem. 72: $248-254$

Burgess R. (2009) Protein precipitation techniques. Meth. Enzymol. 463: 331-342.

Cao L., Van Rantwijk F., Sheldon A. (2000) Cross-linked enzyme aggregates: a simple and effective method for the immobilization of penicillin acylase. Org. Lett. 2: 1361-1364.

Daglioglu C., Zihnioglu F. (2012) Covalent immobilization of trypsin on glutaraldehyde-activated silica for protein fragmentation. Artif Cells. Blood Sub. 40: 378-384.

Dalal S., Kapoor M., Gupta N. (2007) Preparation and characterization of combi-CLEAs catalyzing multiple non-cascade reactions. J. Mol. Catal. B Enzym. 44: 128-132.

Guimarães R., Giordano C., Fernandez-Lafuente R., Tardioli W. (2018) Evaluation of strategies to produce highly porous cross-linked aggregates of porcine pancreas lipase with magnetic properties. Molecules 23: 2993. DOI: 10.3390/molecules23112993.

Homaei A., Sariri R., Vianello F., Stevanato R. (2013) Enzyme immobilization: an update. J. Chem. Biol. 29: 185-205. DOI: $10.1007 / \mathrm{s} 12154-013-0102-9$.

Jain M., Radha P., Kiruthika S., Muthukumaran C., Tamilarasan K. (2016) Synthesis, characterization and kinetic analysis of chitosan coated magnetic nanobiocatalyst and its application on glucose oleate ester synthesis. J. Mol. Catal. B Enzym. 128: 1-9.

Jian C., Shi J. (2015) Optimization protocols and improved strategies of cross-linked enzyme aggregates technology: current development and future challenges. Crit. Rev. Biotechnol. 35: 15-28.

Kamburov M., Lalov I. (2012) Preparation of chitosan beads for trypsin immobilization. Biotechnol. Biotechnol. Equip. 26: 156-163. DOI: 10.5504/50YRTIMB.2011. 0029.

Kim H., Parka S., Kim H., Won K., Lee H. (2013) Immobilization of formate dehydrogenase from Candida boidiniithrough cross-linked enzyme aggregates. J. Mol. Catal. B Enzym. 97: 209-214.
Krajewska B. (2004) Application of chitin- and chitosan-based materials for enzyme immobilizations: a review. Enzyme Microb. Technol. 35: 126-139.

Li X., Yu Z., Bian Z., Xu J., Zhang L., Qiao M. (2018) Physiochemical characterization of $\alpha$-amylase as cross-linked enzyme aggregates. Catalysts 8: 299. DOI: 10.3390/ catal8080299.

Liu C., Saeki D., Matsuyama H. (2017) A novel strategy to immobilize enzymes on microporous membranes via dicarboxylic acid halides. RSC Adv. 7: 48199-48207.

López-Serrano P., Cao L., Van Rantwijk F., Sheldon A. (2002) Cross-linked enzyme aggregates with enhanced activity: application to lipases. Biotechnol. Lett. 24: 1379-1383.

Mahmod S., Yusof F., Jami M., Khanahmadi S. (2016) Optimizing the preparation conditions and characterization of a stable and recyclable cross-linked enzyme aggregate (CLEA)-protease. BIOB 3: 3. DOI: 10.1186/s40643-0150081-5.

Mateo C., Palomo M., Fernandez-Lorente G., Guisan M., Fernandez-Lafuente R. (2007) Improvement of enzyme activity, stability and selectivity via immobilization techniques. Enzyme Microb. Technol. 40: 1451-1463.

Menfaatli E., Zihnioglu F. (2015) Carrier free immobilization and characterization of trypsin. Artif. Cells. Nanomed. Biotechnol. 43: 140-144. DOI: 10.3109/21691401.2013. 853178.

Mohamed S., Abdel-Mageed M., Tayel S., El-Nabrawi M., Fahmy A. (2011) Characterization of Mucor racemosus lipase with potential application for the treatment of cellulite. Process Biochem. 46: 642-648.

Nadar S., Muley B., Ladole R., Joshi U. (2016) Macromolecular cross-linked enzyme aggregates (M-CLEAs) of $\alpha$-amylase. Int. J. Biol. Macromol. 84: 69-78.

Sheldon A. (2011a) Characteristic features and biotechnological applications of cross-linked enzyme aggregates (CLEAs). Appl. Microbiol. Biotechnol. 92: 467-477. DOI: 10.1007/s00253-011-3554-2.

Sheldon R. (2011b) Cross-linked enzyme aggregates as industrial biocatalysts. Org. Process. Res. Dev. 15: 213-223. DOI: $10.1021 /$ op100289f.

Shah S., Sharma A., Gupta N. (2006) Preparation of cross-linked enzyme aggregates by using bovine serum albumin as a proteic feeder. Anal. Biochem. 351: 207-213.

Singh R., Tiwari M., Singh R., Lee J-K. (2013) From protein engineering to immobilization: promising strategies for the upgrade of industrial enzymes. Int. J. Med. Res. 14: 1232-1277. DOI: $10.3390 /$ ijms14011232.

Suleka F., Fernándezb D., Kneza Z., Habulina M., Sheldon R. (2011) Immobilization of horseradish peroxidase as crosslinked enzyme aggregates (CLEAs). Process Biochem. 46: 765-769.

Sun J., Hu K., Liu Y., Pan Y., Yang Y. (2013) Novel superparamagnetic nanoparticles for trypsin immobilization and the application for efficient proteolysis. J. Chromatogr. B 942: 9-14. 
Sun J., Xu B., Shi Y., Yang L., Ma L. (2017) Activity and stability of trypsin immobilized onto chitosan magnetic nanoparticles. Adv. Mater. Sci. Eng. DOI: org/10.1155/2017/ 1457072.

Talekar S., Ghodake V., Ghotage T., Rathod P., Deshmukh P., Nadar S., Mulla, M., Ladole M. (2012) Novel magnetic cross-linked enzyme aggregates (magnetic CLEAs) of alpha amylase. Bioresour. Technol. 123: 542-547.

Talekar S., Joshi A., Joshi G., Kamat P., Haripurkar R., Kambale S. (2013) Parameters in preparation and characterization of cross linked enzyme aggregates (CLEAs). RSC Adv. 3: 12485-12511.

Velasco-Lozano S., López-Gallego F., Mateos-Díaz C., FavelaTorres E. (2015) Cross-linked enzyme aggregates (CLEA) in enzyme improvement - a review. Biocatalysis 1: 166-177.

Wang J., Wang L., Haojie A., Zain-ul-Abdin, Yongsheng C., Qing C., Weidong Z., Hongtao Z., Xiao C. (2016) Recent progress on synthesis, property and application of modified chitosan: an overview. Int. J. Biol. Macromol. 88: 333-344.

Xu Q., Shuang-Shuang W., Li-Na L., Jian G., Ye-Wang Z. (2018) Combined cross linked enzyme aggregates as biocatalysts. Catalysts 8: 460: DOI: 10.3390/catal8100460.

Xu Y., Yang Z. (2013) Cross-linked tyrosinase aggregates for elimination of phenolic compounds from wastewater. Chemosphere 92: 391-398.

Yamaguchi H., Miyazaki M., Asanomi Y., Maeda H. (2011) Poly-lysine supported cross-linked enzyme aggregates with efficient enzymatic activity and high operational stability. Catal. Sci. Technol. 1: 1256-1261.

Yu W., Chen H., Wang X., Yang Y. Ching B. (2006) Cross-linked enzyme aggregates (CLEAs) with controlled particles: application to Candida rugosa lipase. J. Mol. Catal. B Enzym. 43: 124-127. 